\title{
Metformin in the treatment of gestational diabetes mellitus: is it safe and efficient?
}

\author{
Argirios Rountis, Kalliopi Pappa
}

1st Department of Obstetrics and Gynecology, "Alexandra" Maternity Hospital, National and Kapodistrian University of Athens, Athens, Greece.

\section{Correspondence}

Argirios Rountis, email: rountis.argiris@gmail.com

\section{Abstract}

Gestational diabetes mellitus (GDM) typically occurs when maternal glucose metabolism fails to compensate for the gradually increasing insulin resistance which mainly derives from the indigenous production of diabetogenic placental hormones during pregnancy. With its rising prevalence nowadays, GDM constitutes one of the most serious health problems in pregnant women that may result in both maternal and neonatal adverse outcomes if not treated properly. Although most women succeed in controlling their blood glucose levels with diet alone, some require pharmacological treatment in order to achieve adequate glycemic control. For these women, insulin is considered to be the best pharmacological choice for their treatment. However, a growing number of recent studies suggest oral antidiabetic agents to be equivalent if not superior to insulin in terms of safety and efficacy for the treatment of GDM. The objective of this review is to evaluate efficacy and safety of metformin in the treatment of GDM based on the most recent data of the literature.

Key words: Gestational diabetes mellitus, metformin, maternal outcome, neonatal outcome

\section{Introduction}

Gestational diabetes mellitus (GDM) is defined as any degree of carbohydrate intolerance occurring or recognized for the first time during pregnancy resulting in hyperglycemia of variable severity. This definition includes cases of pre-existing type 2 diabetes mellitus (T2DM) that have been diagnosed for the first time early in pregnancy and true gestational diabetes mellitus (GDM) with onset later in preg- nancy that may persist after labor. ${ }^{1}$

Nowadays, the incidence of GDM is estimated at $7-8 \%$ of all pregnancies, affecting approximately 200.000 deliveries in the United States each year. ${ }^{2}$ This condition is associated with both maternal and neonatal adverse outcomes. Maternal implications include preeclampsia, higher caesarean section rate and development of type 2 diabetes mellitus after 
pregnancy. In neonates, GDM may lead to macrosomia, shoulder dystocia, neonatal hypoglycemia, hypocalcemia, hyperbilirubinemia and plethora. Finally, the infants of gestational diabetic mothers have an increased risk of developing both obesity and diabetes later in life. ${ }^{3}$

The management of GDM involves lifestyle modifications such as medical nutrition therapy, exercise, weight management and self-monitoring of maternal blood glucose. If the aforementioned measures do not achieve to control the maternal blood sugar levels, then pharmacological treatment is required. ${ }^{4}$

The gold standard for the pharmacological treatment of GDM is subcutaneous insulin, a US FDA category B drug. However, the insulin therapy has its drawbacks; the unfavorable route of administration in combination with the complicated dosing schedule reduces patient compliance with the treatment. ${ }^{5}$ During the last decade, a growing number of studies suggest oral antidiabetic agents including metformin and glyburide, as a safe and efficient alternative to insulin in the treatment of GDM. ${ }^{6,9-18,24,25}$

The aim of this review is to evaluate the efficacy and safety of metformin in the treatment of GDM based on the most recent data of the literature.

\section{The role of metformin in gestational}

\section{diabetes mellitus}

Metformin is the most commonly used oral hypoglycemic drug in the treatment of non-insulin dependent diabetes mellitus. Being a part of biguanides, it exerts its hypoglycemic effect by suppressing hepatic gluconeogenesis and reducing glucose absorption from the gastrointestinal tract. Moreover, it has an insulin-sensitizing effect on multiple tissues resulting in a gradual increase in the peripheral uptake and utilization of glucose. ${ }^{6}$

Like insulin, metformin is listed as an US FDA category B drug for use during pregnancy, thereby indicating that animal reproduction studies have failed to demonstrate a risk to the fetus, but there are no adequate and well-controlled studies in pregnant women. However, most physicians avoid to use metformin in the treatment of GDM due to the fact that it passes through the placenta and may cause potential toxic effects to the fetus. Currently, there are no guidelines regarding the use of metformin during pregnancy. Thus, the dosage of the drug and the duration of the treatment is totally determined by clinicians based on their personal experience and judgement. $^{7}$

As far as breastfeeding is concerned, data seem to conclude that metformin is safe for the neonates of breastfeeding mothers. The concentrations of the drug in the breast milk are generally low to undetectable, whilst the mean infant exposure to the drug is below the $10 \%$ level concerning breastfeeding. Nevertheless, every mother should previously take into consideration the risk/benefit ratio for her and her infant before proceeding to breastfeeding. ${ }^{8}$

\section{Data comparing metformin to insulin for the treatment of GDM}

During the last decade, the use of metformin as an alternative option for the treatment of gestational diabetes mellitus is gradually gaining popularity among the medical scientific society. An increasing number of studies conducted from both gynecologists and endocrinologists have shown that metformin is superior to insulin in the treatment of GDM resulting in better maternal and neonatal outcomes. However, because of the lack of adequate data, the use of metformin in GDM is currently restricted only to USA, although lately it is increasingly used in Europe and South Africa. The data from the literature seem to support those who suggest the use of this drug for the glycemic control of pregnant women. ${ }^{9-18}$

The concept of metformin use in pregnancy started with Rowan et al in 2008 with MIG (Metformin vs Insulin for the treatment of Gestational di- 
abetes) trial where they reported that the neonates whose mother treated with metformin for GDM suffered less commonly from severe hypoglycemia (glucose level $<1.6 \mathrm{mmol}$ per liter) than those whose mother's GDM was treated with insulin. $(\mathrm{P}=0.008)$. However, in this study, preterm birth (labor before the 37th gestational week) was more common in the metformin group $(\mathrm{P}=0.04)$ still without being associated with a higher rate of neonatal complications. ${ }^{9}$ Later, in 2009, Rai et al published a prospective observational study in which 60 diabetic pregnant women divided in two groups, one treated with metformin whilst the other treated with insulin. The results of this study reported a better glycemic control in the metformin group the first week of the treatment and throughout gestation. $(\mathrm{P}=0.03-0.007)$. Additionally, the same study showed a significant increase in neonatal intensive care unit admission and higher cost of therapy in the insulin group. ${ }^{10}$ As far as birth weight and neonatal morbidity is concerned, Ijäs et al. randomized controlled study in 2010 showed no statistically significant difference between the two groups in any outcome. ${ }^{11}$

In 2011, Rowan et al. (MIG-TOFU) reviewed those women who had participated in the MIG trial when their children were 2 years old. In an attempt to investigate the long term neonatal outcomes of the treatment, they discovered that the children whose mother belong to the metformin group had larger mid-upper arm circumferences $(\mathrm{P}=0.002)$, subscapu$\operatorname{lar}(\mathrm{P}=0.02)$ and biceps skinfolds $(\mathrm{P}=0.04)$, but overall body fat was the same as in children whose mothers were treated with insulin alone. This implies that exposure to metformin in utero led to further fat storage in subcutaneous tissue rather than in ectopic or visceral sites in these children. Those findings create queries whether the use of metformin in GDM can lead to a more insulin sensitive pattern of growth in the offspring of diabetic mothers or not. ${ }^{12}$ At the same time, Goh et al conducted a prospective study in New
Zealand which suggested that the treatment of GDM with metformin offered diabetic mothers better glycemic control, improved neonatal outcomes $(\mathrm{P}=0.004)$ and resulted in fewer preterm deliveries. $(\mathrm{P}=0.005) .{ }^{13}$ These findings are in line with Rai's et al findings ${ }^{10}$ but do not agree with Rowan's et al findings (MIG 2008) ${ }^{9}$ that suggested a higher rate of preterm birth in the metformin treated group.

One year later, in 2012, Gandhi's et al randomized controlled study hinted that the incidence of macrosomia (birth weight $>4 \mathrm{~kg}$ ) was significantly lower in the neonates of diabetic mothers treated with metformin ${ }^{14}$, whilst Tertti's et al study in 2013 implied no significant differences in birth weight between the neonates of the insulin and metformin group ${ }^{15}$. Meanwhile, Spaulonci's et al in their study reported that diabetic pregnant women who treated with metformin presented less weight gain $(\mathrm{P}=0.002)$ and their infants had a lower frequency of neonatal hypoglycemia $(\mathrm{P}=0.032)^{16}$, exactly as the neonates of the metformin group in MIG trial. ${ }^{9}$ However, $26.08 \%$ of the patients in the metformin group required additional insulin so as to preserve their glycemic control.

More recently, a randomized controlled study conducted in 2015 in Pakistan by Ainuddin et al suggested that the use of metformin for the treatment of GDM results in less maternal weight gain $(\mathrm{P}<0.000)$ and reduces the incidence of maternal preeclampsia and neonatal macrosomia $(\mathrm{P}<0.01) .{ }^{17}$ In this study, the percentage of patients in the metformin group needed supplemental insulin for glycemic control was $42.7 \%$, significantly higher than those in Tertti's et $\mathrm{al}^{15}$ and Spaulonci's et $\mathrm{al}^{16}$ studies $(20.9 \%$ and $26.08 \%$ respectively). Patients who required supplemental insulin were more obese with BMI $>30$, had higher blood sugar levels on the OGTT and needed pharmacological treatment for GDM at an earlier gestational age compared to women who maintained euglycemia with metformin alone, implying that obesity and high blood sugar levels constitute predictive fac- 
Table 1. Studies comparing metformin to insulin for the treatment of GDM

\begin{tabular}{|c|c|c|c|c|c|c|}
\hline Author & Year & $\begin{array}{l}\text { Study } \\
\text { characteristics }\end{array}$ & Region & $\begin{array}{l}\text { Number } \\
\text { of patients }\end{array}$ & $\begin{array}{l}\text { Main } \\
\text { outcome }\end{array}$ & Results \\
\hline Rowan et al. (MIG) ${ }^{9}$ & 2008 & RCT & $\begin{array}{l}\text { Australia/ } \\
\text { New Zealand }\end{array}$ & 733 & Neonatal outcome & $\begin{array}{l}\text { Severe hypoglycemia was } \\
\text { less common in the metformin } \\
\text { group ( } \mathrm{P}=0.008) \text {; preterm } \\
\text { birth (<37 gesttional week) } \\
\text { was more common in the } \\
\text { metformin group ( } \mathrm{P}=0.04) \text {; } \\
\text { no significant differences } \\
\text { between the groups in the } \\
\text { neonatal anthropometric } \\
\text { measures or umbilical cord/ } \\
\text { serum insulin concentrations }\end{array}$ \\
\hline Rai et al. ${ }^{10}$ & 2009 & PS & India & 60 & $\begin{array}{l}\text { Glycemic control, } \\
\text { maternal } \\
\text { complications, } \\
\text { perinatal outcomet }\end{array}$ & $\begin{array}{l}\text { Glycemic control was better in } \\
\text { he metformin group after } 1 \\
\text { week of therapy and also } \\
\text { throughout gestation } \\
(\mathrm{P}=0.03-0.007) \text {. } \\
\text { Significant increase in NICU } \\
\text { admission and higher cost of } \\
\text { therapy in the insulin group. }\end{array}$ \\
\hline Ijäs et al. ${ }^{11}$ & 2010 & RCT & Finland & 97 & $\begin{array}{l}\text { LGA, neonatal } \\
\text { morbidity }\end{array}$ & $\begin{array}{l}\text { No significant differences } \\
\text { between the two groups in } \\
\text { any outcome }\end{array}$ \\
\hline $\begin{array}{l}\text { Rowan et al. } \\
\text { (MIG-TOFU) })^{12}\end{array}$ & 2011 & $\mathrm{RCT}$ & $\begin{array}{l}\text { Australia/ } \\
\text { New Zealand }\end{array}$ & 318 & $\begin{array}{l}\text { Long-term } \\
\text { neonatal outcome }\end{array}$ & $\begin{array}{l}\text { At the age of } 2 \text {, children whose } \\
\text { mother were treated with } \\
\text { metformin had larger } \\
\text { mid-upper arm circumferences } \\
(\mathrm{P}=0.002) \text {, subscapular } \\
(\mathrm{P}=0.02) \text { and biceps } \\
\text { skinfolds }(\mathrm{P}=0.04) \text {. }\end{array}$ \\
\hline Goh et al. ${ }^{13}$ & 2011 & PS & New Zealand & 1235 & $\begin{array}{l}\text { Maternal, } \\
\text { neonatal outcome }\end{array}$ & $\begin{array}{l}\text { Metformin group had better } \\
\text { glycemic control, fewer } \\
\text { preterm deliveries }(\mathrm{P}=0.005) \text {, } \\
\text { and improved neonatal } \\
\text { outcomes }(\mathrm{P}=0.004)\end{array}$ \\
\hline Gandhi et al. ${ }^{14}$ & 2012 & RS & UK & 592 & $\begin{array}{l}\text { Maternal, } \\
\text { neonatal outcome }\end{array}$ & $\begin{array}{l}\text { Women in the metformin } \\
\text { group had a significantly } \\
\text { lower incidence of macrosomia } \\
\text { (birth weight > } 4 \mathrm{~kg} \text { ) ( } 8.2 \% \text { vs. } \\
14.3 \% \text { (OR } 0.56 \text {; } 95 \% \text { CI } 0.33- \\
0.99 \text { )), as well as birth weight } \\
>90 \text { th centile ( } 14.8 \% \text { vs. } \\
23.7 \% \text { (OR } 0.56 \text {; } 95 \% \text { CI } 0.37- \\
0.85) \text { ). There were no signifi- } \\
\text { cant differences in maternal } \\
\text { outcome measures between } \\
\text { the groups. }\end{array}$ \\
\hline
\end{tabular}




\begin{tabular}{|c|c|c|c|c|c|c|}
\hline Tertti et al. ${ }^{15}$ & 2013 & RCT & Finland & 217 & Birth weight & $\begin{array}{l}\text { No significant differences in } \\
\text { mean birth weight between } \\
\text { the metformin and insulin } \\
\text { group. } 20.9 \% \text { of the patients } \\
\text { in the metformin group } \\
\text { needed additional insulin. }\end{array}$ \\
\hline Spaulonci et al. ${ }^{16}$ & 2013 & RCT & Brazil & 92 & Glycemic control & $\begin{array}{l}\text { Lower mean glucose levels } \\
\text { were observed in the } \\
\text { metformin group ( } \mathrm{P}=0.020 \text { ), } \\
\text { owing to lower levels after } \\
\text { dinner ( } \mathrm{P}=0.042 \text { ). Mothers in } \\
\text { the metformin group } \\
\text { presented less weight gain } \\
\text { ( } \mathrm{P}=0.002 \text { ) and a lower } \\
\text { frequency of neonatal } \\
\text { hypoglycemia ( } \mathrm{P}=0.032) .26 .08 \% \\
\text { of the women in the met- } \\
\text { formin group required } \\
\text { supplemental insulin for } \\
\text { glycemic control. }\end{array}$ \\
\hline Ainuddin et al. ${ }^{17}$ & 2015 & RCT & Pakistan & 150 & $\begin{array}{l}\text { Maternal, } \\
\text { neonatal outcome }\end{array}$ & $\begin{array}{l}\text { Less maternal weight gain } \\
\text { was found in the metformin } \\
\text { treated groups }(\mathrm{P}<0.000) \\
\text { and the incidence of } \\
\text { preeclampsia in these groups } \\
\text { was significantly lesser in } \\
\text { comparison with the insulin } \\
\text { treated group. Mean birth } \\
\text { weight was significantly less } \\
\text { in metformin treated groups } \\
\text { ( } \mathrm{P}<0.01) \text { so as it was neonatal } \\
\text { morbidity. } 42.7 \% \text { of patients } \\
\text { required supplemental insulin } \\
\text { in the metformin group. }\end{array}$ \\
\hline Ghomian et al. ${ }^{18}$ & 2018 & RCT & Iran & 286 & $\begin{array}{l}\text { Glycemic control, } \\
\text { neonatal outcome }\end{array}$ & $\begin{array}{l}\text { No significant differences in } \\
\text { glycemic control or neonatal } \\
\text { outcomes between the two } \\
\text { groups. }\end{array}$ \\
\hline
\end{tabular}

GDM: Gestational diabetes mellitus, MIG: Metformin versus Insulin for the treatment of gestational diabetes, LGA: Large for gestational age, TOFU: The offspring follow-up, NICU: Neonatal intensive care unit, RCT: Randomized controlled trial, PS: Prospective study, RS: Retrospective study.

tors for the failure of the treatment. Finally, Ghomian et al in their study conducted in Iran in 2018 showed that there are no significant differences in glycemic control or neonatal outcomes between diabetic pregnant women treated with metformin and those treated with subcutaneous insulin. ${ }^{18}$ In table 1 you can see a summary of studies comparing metformin to insulin for GDM management.

\section{Data comparing metformin to glyburide} for the treatment of GDM

Another oral antidiabetic agent that has recently 
been studied for the treatment of GDM with good results is glyburide. Glyburide, also known as Glibenclamide, is a sulfonylurea that reduces blood glucose levels by binding to pancreatic $\beta$-receptors in order to increase insulin secretion in blood. Moreover, it prevents hyperglycemia by enhancing sensitivity of peripheral tissues to insulin. ${ }^{19}$

In the last few years, a small number of studies attempted to compare the efficacy of metformin with glyburide for the treatment of GDM..$^{20-23}$ In 2010, Silva

Table 2. Studies comparing metformin to glyburide for the treatment of GDM.

\begin{tabular}{|c|c|c|c|c|c|c|}
\hline Author & Year & $\begin{array}{l}\text { Study } \\
\text { characteristics }\end{array}$ & Region & $\begin{array}{l}\text { Number } \\
\text { of patients }\end{array}$ & $\begin{array}{l}\text { Main } \\
\text { outcome }\end{array}$ & Results \\
\hline Silva et al. ${ }^{20}$ & 2010 & RCT & Brazil & 72 & $\begin{array}{l}\text { Glycemic control, } \\
\text { neonatal outcome }\end{array}$ & $\begin{array}{l}\text { No significant differences in } \\
\text { any outcome except maternal } \\
\text { weight gain during pregnancy } \\
\text { was less in the metformin } \\
\text { group }(\mathrm{P}=0.02) \text {. }\end{array}$ \\
\hline Moore et al. ${ }^{21}$ & 2010 & RCT & US & 149 & Glycemic control & $\begin{array}{l}\text { No significant differences in } \\
\text { glycemic control between the } \\
\text { two groups. However, the } \\
\text { percentage of women } \\
\text { required supplemental insulin } \\
\text { was } 2.1 \text { times higher in the } \\
\text { metformin group than in the } \\
\text { glyburide group, suggesting a } \\
\text { higher rate of failure with } \\
\text { metformin compared to } \\
\text { glyburide }(\mathrm{P}=0.01) \text {. }\end{array}$ \\
\hline Silva et al. ${ }^{22}$ & 2012 & RCT & Brazil & 198 & Neonatal outcome & $\begin{array}{l}\text { No significant differences } \\
\text { between the two groups } \\
\text { exceptneonatal weight }(\mathrm{P}=0.01) \\
\text { and ponderal index }(\mathrm{P}=0.05) \\
\text { were lower in the metformin } \\
\text { group. Glucose levels at } 1 \text { st } \\
\text { and 3rd hour after birth were } \\
\text { lower in glyburide group } \\
\text { (P=0.01 for both). Maternal } \\
\text { weight gain was lower in the } \\
\text { metformin group }(\mathrm{P}=0.04)\end{array}$ \\
\hline George et al. ${ }^{23}$ & 2015 & RCT & India & 159 & Maternal, & $\begin{array}{l}\text { Women in the metformin } \\
\text { group had significantly } \\
\text { higher fasting triglyceride } \\
\text { levels than those in the } \\
\text { glyburide group }(\mathrm{P}=0.05) \text {. } \\
\text { The incidence of neonatal } \\
\text { hypoglycemia was higher in } \\
\text { the glyburide group ( } \mathrm{P}=0.001) \\
\text { Secondary outcomes in both } \\
\text { groups were similar. }\end{array}$ \\
\hline
\end{tabular}

GDM: Gestational diabetes mellitus, RCT: Randomized controlled trial 
et al in Brazil published a randomized controlled trial of 72 patients in order to evaluate glycemic control and neonatal outcomes in the treatment of GDM with metformin or glyburide. The study showed that there were no significant differences in any outcome but for maternal weight gain, which was less in the metformin treated group ( $7.6 \mathrm{~kg}$ vs $10.3 \mathrm{~kg}, \mathrm{P}=0.02) .{ }^{20}$ At the same time, Moore et al in United States reported in their study that the percentage of women with GDM that were treated with oral antidiabetic agents and required supplemental insulin for adequate glycemic control was 2.1 times higher in the metformin group (34.7\% vs $16.2 \%$ ), indicating a higher rate of success with glyburide in comparison with metformin as far as glycemic control is concerned $(\mathrm{P}=0.01) .{ }^{21}$

Two years later, Silva et al, in their randomized controlled trial conducted in Brazil tried to evaluate the perinatal impact of metformin and glyburide in the treatment of GDM. The results of the trial hinted that metformin was associated with lower maternal weight gain $(\mathrm{P}=0.04)$ and lower neonatal weight $(\mathrm{P}=0.01)$ and ponderal index $(\mathrm{P}=0.05)$, whilst glyburide resulted in lower glucose levels at 1 st and 3rd hour after birth ( $\mathrm{P}=0.01$ for both) ${ }^{22}$ The aforementioned result seems to be in line with George's et al randomized control trial (India, 2015), that showed a higher incidence of neonatal hypoglycemia in the glyburide group. ${ }^{23}$ In table 2 we summarize the studies comparing metformin to glyburide.

\section{Conclusion}

The studies of the literature seem to advocate the use of metformin in diabetic pregnant women indicating that metformin is a safe and efficient alternative to insulin for the treatment of GDM. ${ }^{9-18}$

It is listed as an US FDA category B drug for use during pregnancy and is considered to be safe for breastfeeding mothers and their neonates. ${ }^{7,8}$

Currently there are no guidelines regarding the use of metformin during pregnancy. Most studies suggest an initial dose of $500 \mathrm{mg}$ once or twice a day with food ${ }^{9,14,15,17,18,20,22,23}$ and a gradual increase of the dosage every week until adequate glycemic control is achieved or a maximum dose of $2000-2550 \mathrm{mg} /$ day divided in two or three doses is reached. ${ }^{9,10,14-17,20-}$ ${ }^{23}$ If metformin alone do not achieve to meet glycemic targets then supplemental insulin should be added. ${ }^{9,11,14-17}$ Moreover, metformin should be stopped and replaced by insulin treatment if maternal contraindications (such as renal or liver impairment) develop. ${ }^{9,11,14,15}$

Except for metformin, glyburide, a sulfonylurea with hypoglycemic effect can also be used as an oral anti-diabetic agent in the treatment of GDM. ${ }^{6,20-25}$ However, metformin seems to be a more efficient drug associated with less maternal weight gain and a lower incidence of neonatal hypoglycemia compared to glyburide. ${ }^{20,22,23}$

As far as the treatment of GDM is concerned, metformin compared to insulin, is associated with less maternal weight gain ${ }^{16,17}$, lower incidence of preeclampsia ${ }^{17}$, better maternal glycemic control ${ }^{10,13}$, lower frequency of neonatal hypoglycemia ${ }^{9,16}$ and macrosomia ${ }^{14,17}$. The incidence of preterm birth in the metformin group compared to the insulin group seems to be higher in one study ${ }^{9}$ and lower in another ${ }^{13}$. Those results seem to be attributed to differences regarding the indication for preterm birth (iatrogenic or spontaneous labor, preterm rapture membranes) in each study. One study showed that insulin therapy is more expensive and associated with a significant increase in neonatal intensive care unit admission. ${ }^{10}$

The MIG-TOFU trial showed that children exposed to metformin had larger measures of subcutaneous fat, but overall body fat was the same as in children whose mothers were treated with insulin alone. This suggest that in-utero exposure to metformin may lead to a more insulin sensitive pattern of growth in the offspring of diabetic mothers. However, these 
findings require further examination and clinical research in order to prove their value. ${ }^{12}$

\section{References}

1. Alberti KG, Zimmet PZ. Definition, diagnosis and classification of diabetes mellitus andits complications. Part 1: diagnosis and classification of diabetes mellitus provisional report of a WHO consultation. Diabet Med. 1998 Jul;15(7):539-53

2. Durnwald C. Gestational diabetes: Linking epidemiology, excessive gestational weight gain, adverse pregnancy outcomes, and future metabolic syndrome. Semin Perinatol. 2015 Jun;39(4):254-8.

3. Coustan DR. Gestational diabetes mellitus. Clin Chem. 2013 Sep;59(9):1310-21.

4. Gestational diabetes from A to Z Mirghani Dirar A, Doupis J. World J Diabetes. 2017 Dec 15;8 (12):489-511

5. Schwartz RA, Rosenn B, Aleksa K, Koren G. Glyburide transport across the human placenta. Obstet Gynecol. 2015 Mar;125(3):583-8.

6. Ryu RJ, Hays KE, Hebert MF. Gestational diabetes mellitus management with oral hypoglycemic agents. Semin Perinatol. 2014 Dec;38(8):508-15.

7. Lautatzis ME, Goulis DG, Vrontakis M. Efficacy and safety of metformin during pregnancy in women with gestational diabetes mellitus or polycystic ovary syndrome: a systematic review. Metabolism. 2013 Nov;62(11):1522-34

8. Hale TW, Kristensen JH, Hackett LP, Kohan R, Ilett KF. Transfer of metformin into human milk. Diabetologia. 2002 Nov;45(11):1509-14.

9. Rowan JA, Hague WM, Gao W, Battin MR, Moore MP; MiG Trial Investigators. Metformin versus insulin for the treatment of gestational diabetes. $\mathrm{N}$ Engl J Med. 2008 May 8;358(19):2003-15.

10. Rai L, Meenakshi D, Kamath A. Metformin--a convenient alternative to insulin for Indian women with diabetes in pregnancy. Indian J Med Sci. 2009 Nov;63(11):491-7.
11. Ijäs H, Vääräsmäki M, Morin-Papunen L, Keravuo $\mathrm{R}$ et al. Metformin should be considered in the treatment of gestational diabetes: a prospective randomised study. BJOG. 2011 Jun;118(7):880-5.

12. Rowan JA, Rush EC, Obolonkin V, Battin M, Wouldes T, Hague WM. Metformin in gestational diabetes: the offspring follow-up (MiG TOFU): body composition at 2 years of age. Diabetes Care. 2011 Oct;34(10):2279-84.

13. Goh JE, Sadler L, Rowan J. Metformin for gestational diabetes in routine clinical practice. Diabet Med. 2011 Sep;28(9):1082-7.

14. Gandhi P, Bustani R, Madhuvrata P, Farrell T Introduction of metformin for gestational diabetes mellitus in clinical practice: Has it had an impact?. Eur J Obstet Gynecol Reprod Biol. 2012 Feb;160(2):147-50.

15. Tertti K, Ekblad U, Koskinen P, Vahlberg T, Rönnemaa T. Metformin vs. insulin in gestational diabetes. A randomized study characterizing metformin patients needing additional insulin. Diabetes Obes Metab. 2013 Mar;15(3):246-51.

16. Spaulonci CP, Bernardes LS, Trindade TC, Zugaib M, Francisco RP. Randomized trial of metformin vs insulin in the management of gestational diabetes Am J Obstet Gynecol. 2013 Jul;209 (1):34.e1-7.

17. Ainuddin J, Karim N, Hasan AA, Naqvi SA. Metformin versus insulin treatment in gestational diabetes in pregnancy in a developing country: a randomized control trial. Diabetes Res Clin Pract. 2015 Feb;107(2):290-9.

18. Ghomian N, Vahed SHM, Firouz S, Yaghoubi MA, Mohebbi M, Sahebkar A. The efficacy of metformin compared with insulin in regulating blood glucose levels during gestational diabetes mellitus: A randomized clinical trial. J Cell Physiol. 2018 Sep 7.

19. Rosseti L, Giaccari A, Defonso R. Glucose toxicity. Diabetes Care 1990;13:610-30. 
20. Silva JC, Pacheco C, Bizato J, de Souza BV, Ribeiro TE, Bertini AM. Metformin compared with glyburide for the management of gestational diabetes. Int J Gynaecol Obstet. 2010 Oct;111(1): 37-40.

21. Moore LE, Clokey D, Rappaport VJ, Curet LB. Metformin compared with glyburide in gestational diabetes: a randomized controlled trial. Obstet Gynecol. 2010 Jan;115(1):55-9

22. Silva JC, Fachin DR, Coral ML, Bertini AM. Perinatal impact of the use of metformin and glyburide for the treatment of gestational diabetes mellitus. J Perinat Med. 2012 Jan 10;40(3):225-8.

23. George A, Mathews JE, Sam D, Beck M, Benjamin SJ et al. Comparison of neonatal outcomes in women with gestational diabetes with moderate hyperglycemia on metformin or glibenclamide-a randomised controlled trial. Aust N Z J Obstet Gynaecol. 2015 Feb;55(1):47-52.
24. Langer O, Conway DL, Berkus MD, Xenakis EM, Gonzales O. A comparison of glyburide and insulin in women with gestational diabetes mellitus. N Engl J Med. 2000 Oct 19;343(16):1134-8

25. Nicholson W, Bolen S, Witkop CT et al. Benefits and risks of oral diabetes agents compared with insulin in women with gestational diabetes: a systematic review. Obstet Gynecol. 2009 Jan;113(1):193-205.
Received 18-12-2018

Revised 10-1-2019

Accepted 18-1-2019 